\title{
Mouse models for the central melanocortin system
}

\author{
Florian Bolze $\cdot$ M. Klingenspor
}

Received: 13 February 2009/Accepted: 16 February 2009/Published online: 6 March 2009

(C) Springer-Verlag 2009

\begin{abstract}
Obesity is characterized by an excess storage of body fat and promotes the risk for complex disease traits such as diabetes mellitus and cardiovascular diseases. The obesity prevalence in Europe is rising and meanwhile ranges from 10 to $20 \%$ in men and $15-25 \%$ in women. Body fat accumulation occurs in states of positive energy balance and is favored by interactions among environmental, psychosocial and genetic factors. Energy balance is regulated by a complex neuronal network of anorexigenic and orexigenic neurons which integrates peripheral and central hormonal and neuronal signals relaying information on the metabolic status of organs and tissues in the body. A key component of this network is the central melanocortin pathway in the hypothalamus that elicits metabolic and behavioral adaptations for the maintenance of energy homeostasis. Genetic defects in this system cause obesity in mice and humans. In this review we emphasize mouse models with spontaneous natural mutations as well as targeted mutations that contributed to our understanding of the central melanocortin system function in the control of energy balance.
\end{abstract}

Keywords Energy balance - Melanocortin · Mouse models · Obesity

F. Bolze $(\square) \cdot$ M. Klingenspor Molecular Nutritional Medicine, Else-Kröner-Fresenius-Zentrum, Technische Universität München, Am Forum 5, Freising, 85350 Weihenstephan, Germany e-mail: bolze@wzw.tum.de

\section{Obesity}

Obesity is characterized by an excess of body fat and promotes the risk for the development of complex disease traits like diabetes mellitus, cardiovascular dysfunctions, certain forms of cancer and sleep-breathing disorders. World Health Organization defines obesity by a body mass index (BMI) larger than $30 \mathrm{~kg} / \mathrm{m}^{2}$, whereas overweight is defined by a BMI between 25 and $29.9 \mathrm{~kg} / \mathrm{m}^{2}$. The obesity prevalence in Europe ranges from 10 to $20 \%$ in men and $15-25 \%$ in woman. Body fat mass is influenced by interactions among environmental, psychosocial and genetic factors. Promotion of positive energy balance causes obesity in humans as well as in mice (for review see [4, 20, 33]).

The mouse has proven itself as an excellent model for investigations on human diseases as development and genetics are similar in mouse and man. Furthermore, genetic engineering techniques in the mouse became wellestablished and reliable tools in the last two decades. In this mini review we highlight different mouse models which have been instrumental to study body weight regulation and the development of obesity.

The melanocortin system and its role in the regulation of energy homeostasis

The lipostatic hypothesis for the control of food intake postulates that adipose tissue produces a hormone in proportion to the amount of fat and acts on the central nervous system to reduce feeding and increase energy expenditure for maintaining energy balance [32]. According to this hypothesis, leptin was identified as the peripheral hormonal signal secreted by adipocytes in 
proportion to body fat mass. Positional cloning of leptin substantiated the involvement of the endocrine system in the regulation of body weight [54]. Deficiency of leptin in obese $(o b / o b)$ mice leads to hyperphagia and reduced energy expenditure [16, 30]. Leptin acts on the leptin receptor, a single-transmembrane-domain receptor of the cytokine receptor family. The $d b / d b$ mouse is characterized by severe obesity and carries a naturally occurring mutation in the leptin receptor gene. This mutation causes an aberrant splicing which results in the production of a truncated leptin receptor [11, 28, 37]. Energy-related signals from the periphery (e.g. leptin) are integrated in the arcuate nucleus of the hypothalamus by two subsets of neurons either expressing pro-opiomelanocortin (POMC) or agouti-related protein (AGRP). These neurons project to melanocortin-4-receptor (MC4R) expressing neurons in other hypothalamic regions like the paraventricular nucleus (PVN). In states of high caloric excess, elevated leptin levels stimulate anorexigenic Pomc neurons and inhibit orexigenic Agrp neurons [12, 31]. In second order neurons MC4R-signaling promotes negative energy balance by increasing energy expenditure and reducing food intake [10, 29, 49]. In times of fasting low leptin levels inactivate Pomc neurons and activate Agrp neurons. Agrp release increases food intake and weight gain by inhibiting signaling at the MC4R (for review see [3, 45]) (see Fig. 1).

\section{Mouse models with mutations in the melanocortin system}

In this section we point out mouse models that allowed the compilation of the melanocortin system described above. The below-mentioned mouse models are summarized in Table 1.

Intensive studies in several mouse models helped to analyze the function of certain genes that are part of the central melanocortin system. The first hint towards the role of melanocortins in the regulation of body weight arose from the analysis of the agouti yellow $\left(\mathrm{A}^{\mathrm{y}}\right)$ mouse: this mouse strain encodes a spontaneous and naturally occurring dominant mutation in the agouti gene resulting in a phenotype characterized by yellow fur, increased linear length and severe obesity [2,7]. Normally, agouti protein is transiently expressed in melanocytes to activate the synthesis of yellow pigment (pheomelanin) and inhibit the production of black pigment (eumelanin) through antagonism of the melanocortin-1-receptor (MC1R) (for review see [17]). The agouti mutation leads to ubiquitous agouti protein expression in $\mathrm{A}^{\mathrm{y}}$ mouse which allows it to antagonize MC4R in the brain. Yellow fur color and obesity in the $\mathrm{A}^{\mathrm{y}}$ mouse is caused through inhibition of MC1R and MC4R in skin and hypothalamus, respectively $[6,41]$.

The identification of agouti was the first breakthrough to clarify the role of central melanocortin system in the

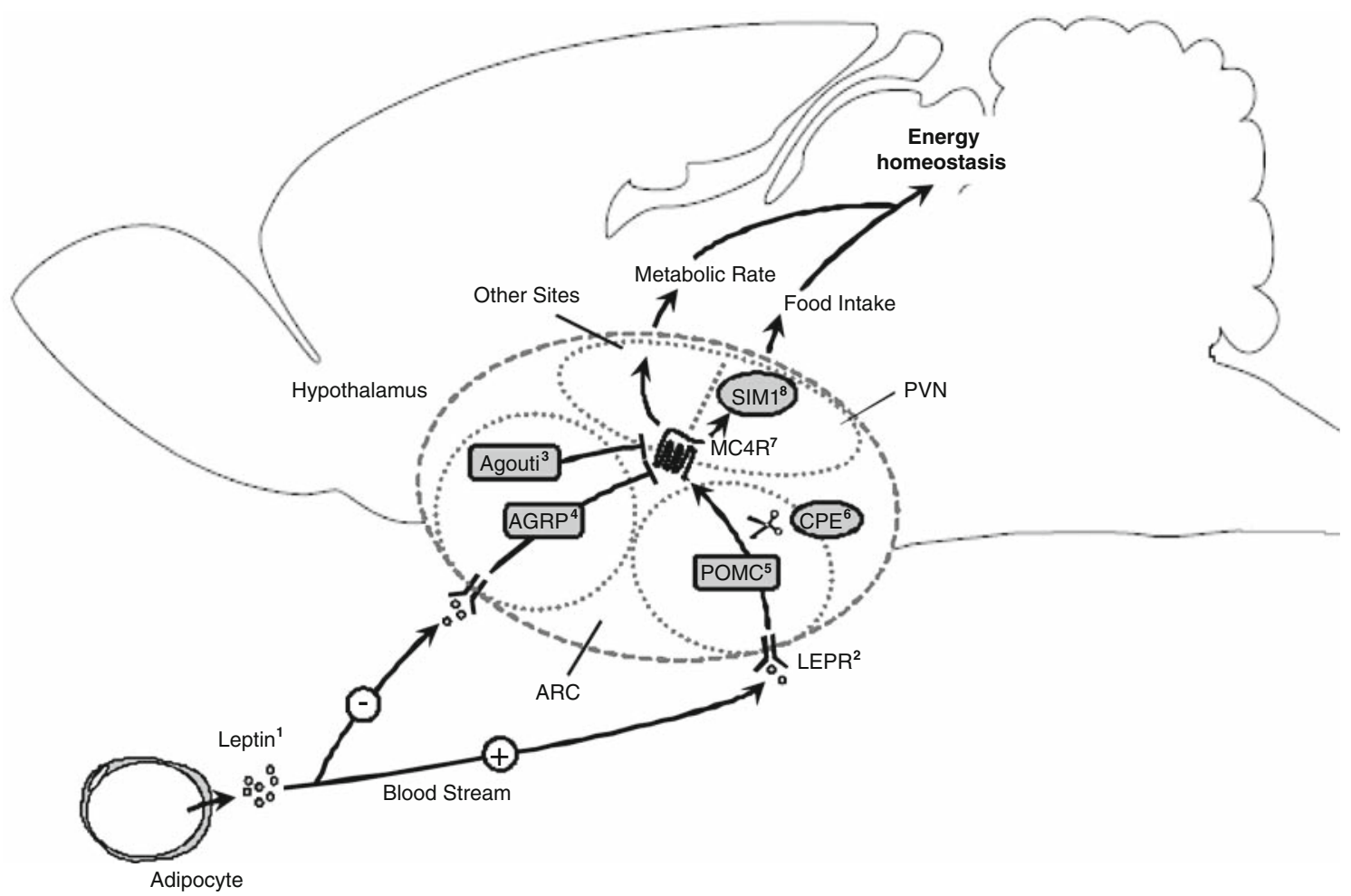

Fig. 1 Schematic representation of the central melanocortin system 
Table 1 Mouse models with mutations in the melanocortin system

\begin{tabular}{|c|c|c|c|c|c|c|c|}
\hline \# & Allele & Gene & Function & Mutation & Effect & $\begin{array}{l}\text { Body } \\
\text { length }\end{array}$ & $\begin{array}{l}\text { Effect on } \\
\text { fur color }\end{array}$ \\
\hline 1 & Obese (ob) & Leptin & $\begin{array}{l}\text { Cytokine hormone secreted } \\
\text { by adipocytes }\end{array}$ & Natural & Loss-of-function & $\downarrow$ & - \\
\hline 2 & Diabetes $(\mathrm{db})$ & Leptin receptor & Cytokine receptor & Natural & Loss-of-function & $\downarrow$ & - \\
\hline 3 & Agouti $\left(\mathrm{A}^{\mathrm{y}}\right)$ & Agouti & Antagonist of Mc1r & Natural & Gain-of-function & $\uparrow$ & + \\
\hline 4 & Agrp & Agouti-related protein & Antagonist of hypothalamic MCRs & Transgenic & Over-expression & $\uparrow$ & - \\
\hline 5 & Pomc & Pro-opiomelanocortin & Protein precursor for MCR agonist & Gene targeting & Knock-out & $\uparrow$ & + \\
\hline 6 & Fat(fat) & Carbooxypeptidase E & Pomc maturation & Natural & Loss-of-function & - & - \\
\hline 7 & $\mathrm{Mc} 4 \mathrm{r}$ & Melanocortin-4- receptor & $\begin{array}{l}\text { Integration of energy related } \\
\text { peripheral signals }\end{array}$ & Gene targeting & Knock-out & $\uparrow$ & - \\
\hline 8 & Sim1 & Single-minded 1 & Putative target of MC4R signaling & Gene targeting & Loss-of-function, & $\uparrow$ & - \\
\hline
\end{tabular}

regulation of energy balance. Based on sequence similarity with agouti, a novel gene was identified and named agoutirelated peptide (Agrp). Generation of transgenic mice that over-express agouti or Agrp demonstrated that both mouse models develop obesity. But only agouti mutants had a yellow fur color phenotype [46]. This finding indicated that Agrp does not inhibit Mc1r function in the skin but is involved in antagonizing a paralog of $\mathrm{Mc} 1 \mathrm{r}$ in the brain.

Subsequently, the identification of Mc4r as the melanocortin receptor in the central nervous system that is antagonized by agouti and Agrp was enabled by a knockout experiment in mice. Disruption of Mc4r by gene targeting results in a phenotype similar to that observed in the $\mathrm{A}^{\mathrm{y}}$ mouse characterized by maturity onset obesity, hyperphagia, hyperinsulinemia and hyperglycemia but without effects on fur color [29]. This knock-out model disclosed a novel signaling pathway for the regulation of body weight and demonstrated that the obesity syndrome of $\mathrm{A}^{\mathrm{y}}$ mice is caused by antagonism of Mc4r by agouti protein. Measurements of metabolic rate in young wildtype and Mc4r-null mice with similar body weights showed that mice deficient for Mc4r consumed less oxygen than wild-type animals. Pair-fed Mc4r knock-out mice gained more weight compared to their wild-type littermates when fed the same amount of food, supporting the idea that $\mathrm{Mc} 4 \mathrm{r}$ deficient animals have a reduced energy expenditure [49]. Moreover, Mc4r knock-out mice are insensitive to the effect of the synthetic melanocortin receptor agonist melanotan II (MTII). Intraperitoneal administration of MTII increases metabolic rate and reduces food consumption in wild-type animals but fails to promote the same effects in Mc4r-null mice [10]. The inhibitory effect of MTII on feeding is completely blocked by intracerebroventricular co-administration of the synthetic agouti mimetic SHU9119 [13]. These results demonstrate that Mc4r mediates control of food intake and metabolic rate in mice.
Furthermore, Mc4r signaling influences preferences to different macronutrients. Intraperitoneal injection of MTII decreases fat consumption in mice in a dose-dependent manner. This effect requires Mc4r since Mc4r-deficient animals do not respond to MTII treatment. Protein and carbohydrate intake are unaffected by MTII treatment [48].

The endogenous agonists of Mc4r originate from a common precursor polypeptide termed pro-opiomelanocortin (Pomc). Pomc-derived peptides have various physiological functions, including pigmentation, adrenocortical activity and regulation of energy homeostasis. Pomc is a large protein precursor that is cleaved by prohormone convertases to smaller bioactive neuropeptides like the Mc4r-agonists $\alpha$-/ $\beta$-melanocyte stimulating hormone (Msh). Deficiency of Pomc in knock-out mice causes multiple dysfunctions in pigmentation and adrenal development. The obesity syndrome of Pomc-null mice resembles characteristics of $\mathrm{Mc} 4 \mathrm{r}$ knock-out and $\mathrm{A}^{\mathrm{y}}$ mice like increased linear growth and hyperphagia, allegeable by reduced Mc4r signaling in hypothalamus [9]. In humans, Pomc mutations are associated with obesity, adrenal insufficiency and red hair pigmentation [5, 24, 34].

Mutations in enzymes involved in the maturation of melanocortin ligands are responsible for the development of obesity. For example, carboxypeptidase E (Cpe), an exopeptidase involved in processing of preprohormones like Pomc, cleaves C-terminal amino acid residues to generate bioactive molecules. An involvement of Cpe in regulation of energy homeostasis is highlighted by the analysis of Cpe-deficient mice $\left(\mathrm{Cpe}^{f a t} / \mathrm{Cp} e^{f a t}\right)$. This naturally occurring mutation results in severe obesity accompanied by low levels of the mature $\alpha$-MSH [8].

Attractin (Atrn) is a widely expressed transmembrane protein whose loss-of-function in mahogany mutant mice $\left(A t^{\mathrm{mg}}{ }^{\mathrm{mg}}\right.$ ) rescues the pleiotropic effects of the $\mathrm{A}^{\mathrm{y}}$ mutation, e.g. Atrn suppresses the development of yellow fur color and obesity [2, 19, 43, 44]. Based on this observation Atrn 
was described as the first obesity suppressor gene. This finding implicates that Atrn in the $\mathrm{A}^{\mathrm{y}}$ mouse is required for agouti to effectively antagonize Mc1r and Mc4r in skin and in the brain, respectively. Furthermore, this finding has raised the possibility that Atrn has a function in Agrp signaling. However, the Atrn ${ }^{\mathrm{mg}}$ mutation does not suppress obesity induced by Agrp over-expression not excluding that a molecule similar to Atrn is involved in Agrp action [22]. For example, a yeast two-hybrid screen utilizing the intracellular domain of MC4R as bait led to the discovery of an attractin-like protein (Alp) which is highly coexpressed with MC4R in the PVN of mice [21]. The Alp binding motif in Mc4r contains a putative phosphorylation site indicating that Alp might play a role in Mc4r trafficking. Alp knock-out mice appear normal with no alterations in body weight or pigmentation [51]. Further experiments using double mutants over-expressing Agrp and deficient for ALP could elucidate possible interaction of these two proteins in vivo.

Recently, a putative downstream mediator of Mc4r signaling pathway was investigated in different mouse models. Sim1 (single-minded), a transcription factor involved in neurogenesis, was identified in a girl with early onset obesity most likely caused by increased food intake rather than diminished energy expenditure [26]. Molecular genetics revealed a chromosomal translocation which disrupts the $\operatorname{Sim} 1$ gene. Interestingly, $\operatorname{Sim} 1$ is highly expressed in the PVN of the hypothalamus [42]. Sim1 heterozygous mice develop hyperphagic obesity, increased linear growth, hyperinsulinemia and elevated feeding efficiency [27]. MTII injection fails to reduce food intake in Sim1 heterozygous mice. But like in wild-type mice, metabolic rate in Sim1 heterozygous mice is increased in response to MTII treatment [35]. BAC transgenic mice over-expressing Sim1 are resistant to diet-induced obesity. Over-expression of Sim1 partially rescues the obese phenotype of $\mathrm{A}^{\mathrm{y}}$ mice by normalizing food intake. However, Sim1 over-expression does not affect energy expenditure [36]. These data led to the suggestion that Sim1 acts downstream of Mc4r. Neither Sim1 overexpression nor haploinsufficiency alter metabolic rate thus indicating that the function of Sim1 is limited to the regulation of food intake. Divergence in Mc4r pathways regulating food intake versus energy expenditure was revealed by utilizing a gene targeted mouse carrying a loxP-flanked transcriptional blocker between the transcriptional start site and the start codon of the Mc4r exon. Expression of Cre-recombinase under the control of Sim1 promotor deletes the transcriptional blocker and allows Mc4r expression specifically in neurons of the PVN and the amygdala. Metabolic phenotyping of these mice demonstrated that PVN/amygdala-specific restoration of Mc4r completely rescued hyperphagia but has no effect on energy expenditure [1]. In conclusion Mc4r in PVN and possibly also in the amygdala regulates feeding, whereas $\mathrm{Mc} 4 \mathrm{r}$ expressed elsewhere in the central nervous system is responsible for the regulation of energy expenditure.

\section{Mouse models for the analysis of gene variants}

Transgenic animals are a powerful tool to investigate the biological function of genes. Furthermore, genetically engineered mouse lines could help to reveal the effect of certain alleles on metabolism. For instance, mutations in the MC4R gene are the most common form of monogenic obesity in humans. Humans encoding MC4R mutations display an obesity syndrome similar to that observed in MC4R-null mice. About $6 \%$ of severe obese subjects carry point mutations in or near the MC4R gene $[15,38,50]$. Investigation of signaling activities of these mutant MC4Rs in assays based on cell culture demonstrated that the characteristic of obesity correlates with dysfunctions in receptor properties [14, 25, 39, 52]. The most common MC4R polymorphism V103I is negatively associated with obesity [18], a finding meanwhile replicated in several independent studies [18, 23, 47, 53]. Despite of a negative association of V103I with obesity, a strong pharmacological phenotype of this mutant receptor expressed in cell culture was not identified. Only one report demonstrated a lower potency of orexigenic AGRP on V103I corresponding to the distribution of this allele in population screens [52]. Several point mutations in the Mc4r gene introduced by chemical mutagenesis have been shown to cause different severity of obesity in mice [40]. Mouse lines encoding certain point mutations of interest are required to elucidate the effects of certain alleles on metabolism in vivo.

Mouse models are a valuable tool to gain insights into the function of genes and their implications for the development of metabolic diseases like obesity. Compared to several non-mammalian animal models the mouse permits transferability on human genetic diseases due to the high degree of similarity between the murine and human genome. Furthermore, targeted mutations by homologous recombination are exclusively feasible in murine embryonic stem cells. The introduction of targeted mutations in the mouse may be useful for the functional analysis of certain genes and polymorphisms that are associated with metabolic phenotypes in humans. Nevertheless mouse models show limitations: human diseases like obesity are caused by interplay among several factors like genes, environment, psychological and cultural influences. Though mouse models are not suitable to investigate the impact of complex social factors on the etiology of human diseases they can contribute significantly to elucidate the 
role of genetic factors as demonstrated by the function of melanocortins in the regulation of energy balance.

Acknowledgments This work was funded by the National Research Network NGFN plus 01GS0822 to M. Klingenspor.

\section{References}

1. Balthasar N, Dalgaard LT, Lee CE, Yu J, Funahashi H, Williams T, Ferreira M, Tang V, McGovern RA, Kenny CD, Christiansen LM, Edelstein E, Choi B, Boss O, Aschkenasi C, Zhang CY, Mountjoy K, Kishi T, Elmquist JK, Lowell BB (2005) Divergence of melanocortin pathways in the control of food intake and energy expenditure. Cell 123:493-505

2. Barsh GS, Ollmann MM, Wilson BD, Miller KA, Gunn TM (1999) Molecular pharmacology of Agouti protein in vitro and in vivo. Ann NY Acad Sci 885:143-152

3. Barsh GS, Schwartz MW (2002) Genetic approaches to studying energy balance: perception and integration. Nat Rev Genet 3:589-600

4. Bessesen DH (2008) Update on obesity. J Clin Endocrinol Metab 93:2027-2034

5. Biebermann H, Castaneda TR, van Landeghem F, von Deimling A, Escher F, Brabant G, Hebebrand J, Hinney A, Tschop MH, Gruters A, Krude H (2006) A role for beta-melanocyte-stimulating hormone in human body-weight regulation. Cell Metab 3:141-146

6. Bultman SJ, Michaud EJ, Woychik RP (1992) Molecular characterization of the agouti locus. Cell 71:1195-1204

7. Castle WE, Little CC (1910) On a modified Mendelian ratio among yellow mice. Science 32:868-870

8. Che FY, Fricker LD (2002) Quantitation of neuropeptides in Cpe(fat)/Cpe(fat) mice using differential isotopic tags and mass spectrometry. Anal Chem 74:3190-3198

9. Chen AS, Marsh DJ, Trumbauer ME, Frazier EG, Guan XM, Yu H, Rosenblum CI, Vongs A, Feng Y, Cao L, Metzger JM, Strack AM, Camacho RE, Mellin TN, Nunes CN, Min W, Fisher J, Gopal-Truter S, MacIntyre DE, Chen HY, van der Ploeg LH (2000) Inactivation of the mouse melanocortin-3 receptor results in increased fat mass and reduced lean body mass. Nat Genet 26:97-102

10. Chen AS, Metzger JM, Trumbauer ME, Guan XM, Yu H, Frazier EG, Marsh DJ, Forrest MJ, Gopal-Truter S, Fisher J, Camacho RE, Strack AM, Mellin TN, MacIntyre DE, Chen HY, van der Ploeg LH (2000) Role of the melanocortin-4 receptor in metabolic rate and food intake in mice. Transgenic Res 9:145-154

11. Chen H, Charlat O, Tartaglia LA, Woolf EA, Weng X, Ellis SJ, Lakey ND, Culpepper J, Moore KJ, Breitbart RE, Duyk GM, Tepper RI, Morgenstern JP (1996) Evidence that the diabetes gene encodes the leptin receptor: identification of a mutation in the leptin receptor gene in $\mathrm{db} / \mathrm{db}$ mice. Cell 84:491-495

12. Cone RD (2005) Anatomy and regulation of the central melanocortin system. Nat Neurosci 8:571-578

13. Fan W, Boston BA, Kesterson RA, Hruby VJ, Cone RD (1997) Role of melanocortinergic neurons in feeding and the agouti obesity syndrome. Nature 385:165-168

14. Farooqi IS, Keogh JM, Yeo GS, Lank EJ, Cheetham T, O'Rahilly S (2003) Clinical spectrum of obesity and mutations in the melanocortin 4 receptor gene. N Engl J Med 348:1085-1095

15. Farooqi IS, Yeo GS, Keogh JM, Aminian S, Jebb SA, Butler G, Cheetham T, O'Rahilly S (2000) Dominant and recessive inheritance of morbid obesity associated with melanocortin 4 receptor deficiency. J Clin Invest 106:271-279
16. Friedman JM, Halaas JL (1998) Leptin and the regulation of body weight in mammals. Nature 395:763-770

17. Garcia-Borron JC, Sanchez-Laorden BL, Jimenez-Cervantes C (2005) Melanocortin-1 receptor structure and functional regulation. Pigment Cell Res 18:393-410

18. Geller F, Reichwald K, Dempfle A, Illig T, Vollmert C, Herpertz S, Siffert W, Platzer M, Hess C, Gudermann T, Biebermann H, Wichmann HE, Schafer H, Hinney A, Hebebrand J (2004) Melanocortin-4 receptor gene variant I103 is negatively associated with obesity. Am J Hum Genet 74:572-581

19. Gunn TM, Miller KA, He L, Hyman RW, Davis RW, Azarani A, Schlossman SF, Duke-Cohan JS, Barsh GS (1999) The mouse mahogany locus encodes a transmembrane form of human attractin. Nature 398:152-156

20. Hainer V, Toplak H, Mitrakou A (2008) Treatment modalities of obesity: what fits whom? Diabetes Care 31(Suppl 2):S269-S277

21. Haqq AM, Rene P, Kishi T, Khong K, Lee CE, Liu H, Friedman JM, Elmquist JK, Cone RD (2003) Characterization of a novel binding partner of the melanocortin-4 receptor: attractin-like protein. Biochem J 376:595-605

22. He L, Gunn TM, Bouley DM, Lu XY, Watson SJ, Schlossman SF, Duke-Cohan JS, Barsh GS (2001) A biochemical function for attractin in agouti-induced pigmentation and obesity. Nat Genet 27:40-47

23. Heid IM, Vollmert C, Hinney A, Doring A, Geller F, Lowel H, Wichmann HE, Illig T, Hebebrand J, Kronenberg F (2005) Association of the 103I MC4R allele with decreased body mass in 7937 participants of two population based surveys. J Med Genet 42:e21

24. Hinney A, Becker I, Heibult O, Nottebom K, Schmidt A, Ziegler A, Mayer H, Siegfried W, Blum WF, Remschmidt H, Hebebrand J (1998) Systematic mutation screening of the pro-opiomelanocortin gene: identification of several genetic variants including three different insertions, one nonsense and two missense point mutations in probands of different weight extremes. J Clin Endocrinol Metab 83:3737-3741

25. Ho G, MacKenzie RG (1999) Functional characterization of mutations in melanocortin-4 receptor associated with human obesity. J Biol Chem 274:35816-35822

26. Holder JL Jr, Butte NF, Zinn AR (2000) Profound obesity associated with a balanced translocation that disrupts the SIM1 gene. Hum Mol Genet 9:101-108

27. Holder JL Jr, Zhang L, Kublaoui BM, DiLeone RJ, Oz OK, Bair CH, Lee YH, Zinn AR (2004) Sim1 gene dosage modulates the homeostatic feeding response to increased dietary fat in mice. Am J Physiol Endocrinol Metab 287:E105-E113

28. Hummel KP, Dickie MM, Coleman DL (1966) Diabetes, a new mutation in the mouse. Science 153:1127-1128

29. Huszar D, Lynch CA, Fairchild-Huntress V, Dunmore JH, Fang Q, Berkemeier LR, Gu W, Kesterson RA, Boston BA, Cone RD, Smith FJ, Campfield LA, Burn P, Lee F (1997) Targeted disruption of the melanocortin- 4 receptor results in obesity in mice. Cell 88:131-141

30. Ingalls AM, Dickie MM, Snell GD (1950) Obese, a new mutation in the house mouse. J Hered 41:317-318

31. Jobst EE, Enriori PJ, Cowley MA (2004) The electrophysiology of feeding circuits. Trends Endocrinol Metab 15:488-499

32. Kennedy GC (1953) The role of depot fat in the hypothalamic control of food intake in the rat. Proc R Soc Lond B Biol Sci 140:578-596

33. Kopelman PG (2000) Obesity as a medical problem. Nature 404:635-643

34. Krude H, Biebermann H, Luck W, Horn R, Brabant G, Gruters A (1998) Severe early-onset obesity, adrenal insufficiency and red hair pigmentation caused by POMC mutations in humans. Nat Genet 19:155-157 
35. Kublaoui BM, Holder JL Jr, Gemelli T, Zinn AR (2006) Sim1 haploinsufficiency impairs melanocortin-mediated anorexia and activation of paraventricular nucleus neurons. Mol Endocrinol 20:2483-2492

36. Kublaoui BM, Holder JL Jr, Tolson KP, Gemelli T, Zinn AR (2006) SIM1 overexpression partially rescues agouti yellow and diet-induced obesity by normalizing food intake. Endocrinology 147:4542-4549

37. Lee GH, Proenca R, Montez JM, Carroll KM, Darvishzadeh JG, Lee JI, Friedman JM (1996) Abnormal splicing of the leptin receptor in diabetic mice. Nature 379:632-635

38. Loos RJ, Lindgren CM, Li S, Wheeler E, Zhao JH, Prokopenko I, Inouye M, Freathy RM, Attwood AP, Beckmann JS, Berndt SI, Prostate, Lung, Colorectal, and Ovarian (PLCO) Cancer Screening Trial, Jacobs KB, Chanock SJ, Hayes RB, Bergmann S, Bennett AJ, Bingham SA, Bochud M, Brown M, Cauchi S, Connell JM, Cooper C, Smith GD, Day I, Dina C, De S, Dermitzakis ET, Doney AS, Elliott KS, Elliott P, Evans DM, Sadaf Farooqi I, Froguel P, Ghori J, Groves CJ, Gwilliam R, Hadley D, Hall AS, Hattersley AT, Hebebrand J, Heid IM, KORA, Lamina C, Gieger C, Illig T, Meitinger T, Wichmann HE, Herrera B, Hinney A, Hunt SE, Jarvelin MR, Johnson T, Jolley JD, Karpe F, Keniry A, Khaw KT, Luben RN, Mangino M, Marchini J, McArdle WL, McGinnis R, Meyre D, Munroe PB, Morris AD, Ness AR, Neville MJ, Nica AC, Ong KK, O'Rahilly S, Owen KR, Palmer CN, Papadakis K, Potter S, Pouta A, Qi L, Nurses' Health Study, Randall JC, Rayner NW, Ring SM, Sandhu MS, Scherag A, Sims MA, Song K, Soranzo N, Speliotes EK, Diabetes Genetics Initiative, Syddall HE, Teichmann SA, Timpson NJ, Tobias JH, Uda M, SardiNIA Study, Vogel CI, Wallace C, Waterworth DM, Weedon MN, Wellcome Trust Case Control Consortium, Willer CJ, FUSION, Wraight, Yuan X, Zeggini E, Hirschhorn JN, Strachan DP, Ouwehand WH, Caulfield MJ, Samani NJ, Frayling TM, Vollenweider P, Waeber G, Mooser V, Deloukas P, McCarthy MI, Wareham NJ, Barroso I, Jacobs KB, Chanock SJ, Hayes RB, Lamina C, Gieger C, Illig T, Meitinger T, Wichmann HE, Kraft P, Hankinson SE, Hunter DJ, Hu FB, Lyon HN, Voight BF, Ridderstrale M, Groop L, Scheet P, Sanna S, Abecasis GR, Albai G, Nagaraja R, Schlessinger D, Jackson AU, Tuomilehto J, Collins FS, Boehnke M, Mohlke KL (2008) Common variants near MC4R are associated with fat mass, weight and risk of obesity. Nat Genet 40:768-775

39. Lubrano-Berthelier C, Durand E, Dubern B, Shapiro A, Dazin P, Weill J, Ferron C, Froguel P, Vaisse C (2003) Intracellular retention is a common characteristic of childhood obesity-associated MC4R mutations. Hum Mol Genet 12:145-153

40. Meehan TP, Tabeta K, Du X, Woodward LS, Firozi K, Beutler B, Justice MJ (2006) Point mutations in the melanocortin-4 receptor cause variable obesity in mice. Mammal Genome 17:1162-1171

41. Michaud EJ, Bultman SJ, Klebig ML, Van Vugt MJ, Stubbs LJ, Russell LB, Woychik RP (1994) A molecular model for the genetic and phenotypic characteristics of the mouse lethal yellow (Ay) mutation. Proc Natl Acad Sci 91:2562-2566

42. Michaud JL, Rosenquist T, May NR, Fan CM (1998) Development of neuroendocrine lineages requires the bHLH-PAS transcription factor SIM1. Genes Dev 12:3264-3275

43. Miller KA, Gunn TM, Carrasquillo MM, Lamoreux ML, Galbraith DB, Barsh GS (1997) Genetic studies of the mouse mutations mahogany and mahoganoid. Genetics 146:1407-1415

44. Nagle DL, McGrail SH, Vitale J, Woolf EA, Dussault BJ Jr, DiRocco L, Holmgren L, Montagno J, Bork P, Huszar D, Fairchild-Huntress V, Ge P, Keilty J, Ebeling C, Baldini L, Gilchrist J, Burn P, Carlson GA, Moore KJ (1999) The mahogany protein is a receptor involved in suppression of obesity. Nature 398:148152

45. O'Rahilly S, Yeo GS, Farooqi IS (2004) Melanocortin receptors weigh in. Nat Med 10:351-352

46. Ollmann MM, Wilson BD, Yang YK, Kerns JA, Chen Y, Gantz I, Barsh GS (1997) Antagonism of central melanocortin receptors in vitro and in vivo by agouti-related protein. Science 278:135-138

47. Rong R, Tao YX, Cheung BM, Xu A, Cheung GC, Lam KS (2006) Identification and functional characterization of three novel human melanocortin-4 receptor gene variants in an obese Chinese population. Clin Endocrinol (Oxf) 65:198-205

48. Samama P, Rumennik L, Grippo JF (2003) The melanocortin receptor MCR4 controls fat consumption. Regul Pept 113:85-88

49. Ste ML, Miura GI, Marsh DJ, Yagaloff K, Palmiter RD (2000) A metabolic defect promotes obesity in mice lacking melanocortin4 receptors. Proc Natl Acad Sci USA 97:12339-12344

50. Vaisse C, Clement K, Durand E, Hercberg S, Guy-Grand B, Froguel P (2000) Melanocortin-4 receptor mutations are a frequent and heterogeneous cause of morbid obesity. J Clin Invest 106:253-262

51. Walker WP, Aradhya S, Hu CL, Shen S, Zhang W, Azarani A, Lu X, Barsh GS, Gunn TM (2007) Genetic analysis of attractin homologs. Genesis 45:744-756

52. Xiang Z, Litherland SA, Sorensen NB, Proneth B, Wood MS, Shaw AM, Millard WJ, Haskell-Luevano C (2006) Pharmacological characterization of 40 human melanocortin-4 receptor polymorphisms with the endogenous proopiomelanocortinderived agonists and the agouti-related protein (AGRP) antagonist. Biochemistry 45:7277-7288

53. Young EH, Wareham NJ, Farooqi S, Hinney A, Hebebrand J, Scherag A, O'Rahilly S, Barroso I, Sandhu MS (2007) The V103I polymorphism of the MC4R gene and obesity: population based studies and meta-analysis of 29563 individuals. Int J Obes (Lond) 31:1437-1441

54. Zhang Y, Proenca R, Maffei M, Barone M, Leopold L, Friedman JM (1994) Positional cloning of the mouse obese gene and its human homologue. Nature 372:425-432 